\title{
A Comparative Study on the Work-Life Balance Certification Systems of Korean Government
}

\author{
Ok Hee Park, Doctoral Student, Dept. of Smart Convergence Consulting, Hansung University, 02876, Korea, \\ okino2@naver.com \\ Yen-Yoo You, Professor, Dept. of Smart Convergence Consulting, Hansung University, 02876, Korea, \\ threey0818@hansung.ac.kr \\ *Seok Kee Lee, Professor, Dept. of Computer Engineering, Hansung University, 02876, Korea, \\ seelee@hansung.ac.kr \\ *Corresponding Author
}

\begin{abstract}
With COVID-19 Pandemic, workers' work-life balance is being reexamined as telecommuting expands in terms of "social distance" and "corporate risk" management. For this, a comparative study was conducted on the work-life balance certifications currently operated by the Korean government. The first is the "Family Friendly Certification (FFC)" by the Ministry of Gender Equality and Family, the "Work Innovative Incentive Certification (WIIC)" by the Ministry of Employment and Labor, and the third is the "Leisure Friendly Management Certification (LFMC)" by the Ministry of Culture, Sports and Tourism. In the comparative analysis, the government agency's policy data, statistics, press releases, website announcements, and public-private research reports were reviewed for empirical analysis. According to the analysis, the work and life balance certification of the Republic of Korea is related to low birth rates and aging policies such as shortening working hours, flexible work, and maternity protection. It also provides policy incentives for company to produce financial and non-financial results. It is meaningful that the findings of this study can help a lot of SMEs which are considering the adoption of the work-life balance system by providing the pros and cons of the currently existing certification systems. Moreover, this research would be a pioneering study because there is little comparative research on the various work-life balance certification systems.
\end{abstract}

Keywords: Family-Friendly Certification, Work Innovation Incentive Certification, Leisure Friendly Management Certification, Family-Friendly Management. flexible work system

Received: $10.12 .2020 \quad$ Accepted: $12.01 .2021 \quad$ Published: 03.02.2021

\section{INTRODUCTION}

Korea's gross domestic product (GDP) is the world's 10th largest, and as a model country for COVID-19 measures, it has created ' $\boldsymbol{K}$-quarantine management standards' and received love calls from around the world. But As of 2019, the annual working hours of Korean workers are 1,967 hours, the third longest among OECD member countries after Mexico (2,137 hours) and Costa Rica (2,060 hours) [1]. These overtime work can cause workers to overwork and increase the cardiovascular disease. Al so South Korea has a suicide rate of 23 per 100,000 people, ranking first in the OECD [2]. The OECD's 2020 Quality of Life report showed that complaints such as long working hours and low wages were high, the lowest among member countries [3]. On the other hand, the reason for the high youth unemployment rate in Korea is that job seekers are reluctant to join small and medium-sized businesses. Small and medium-sized businesses have jobs, but they have fewer salaries and welfare than large corporations, and their vision is opaque, making it difficult to secure the workforce [4]. In order to solve these social problems, the government has implemented policies such as providing youth employment assistance and providing consulting on work-life balance for small and medium-sized enterprises [5]. Nevertheless, the government is implementing various policies to solve complex social problems. The recent introduction of a 52-hour workweek in Korea has raised interest in work-life balance [6]. In April 2020, the Deputy Minister of Gender Equality and Family emphasized the need to spread a family-friendly management culture, emphasizing that "in the crisis of COVID-19, it is absolutely necessary for companies to take full advantage of family-friendly systems such as flexible working systems and family-friendly vacations."[7]. Meanwhile, in Europe, we recognize the importance of working-life balance for workers and are improving policies such as spousal maternity leave, and parental leave [8]. In this situation, the Government of The Republic of Korea operates a certification and incentive system to help companies 
voluntarily improve the environment associated with workers' work-life balance. However, as the certification system of similar names is operated, it is necessary to try to determine which certification is appropriate for our company from a company standpoint. Therefore, it was necessary to study the Korea's work-life balance system, which is related to the happiness of the people, has an important effect on solving the problem of working hours [9], and affects the productivity of the company[10]. To this end, we will examine legal and policy trends in depth through a comparative analysis of family-friendly certification, leisure-friendly management certification, and work innovation incentive system, identify common and differences, and help companies discuss and propose policy diffusion measures with the aim of introducing the system.

\section{Materials and Methods}

\section{Concepts and Status of Family-Friendly Certification (FFC)}

The Family-Friendly Certification (Hereafter referred to as FFC) is a system that examines and certifies companies or public institutions that exemplify the family-friendly system. This system is introduced for family-friendly management to combine work and family life with low birth rates, aging populations, increased social activities for women, and changes in social values [11]. FFC started in 2008 with nine (three large corporations, six public institutions) and increased every year, with 3,833 companies being certified as of 2019. $408(10.6 \%), 980$ public institutions (25.6\%) and 2,445 (63.8\%) It consists of small and medium-sized enterprises. Certified companies consist of 1,410 manufacturing, 854 public administration, defense and social security administrations, 160 electrical, gas, steam and air conditioning supply, 272 wholesale retail businesses, 244 telecommunications and telecommunications businesses, 560 various services, 166 construction businesses, and 167 other industries [12]. This quantitative increase is believed to have had a significant impact on the implementation of mandatory certification of public institutions in 2017. Family-friendly certification has a lot of screening indicators and a lot to prepare for compared to other certification systems, and the percentage of small and medium-sized enterprises that are eliminated from certification is higher than that of large corporations and public institutions [13].

\section{Concept and Status of Leisure Friendly Management Certification (LFMC)}

The Ministry of Culture, Sports and Tourism's Leisure-Friendly Management Certification (Hereafter referred to as LFMC) is a system that selects, certifies, and supports companies that are exemplary in helping workers harmonize their work and leisure life [14]. In order to create a social atmosphere for "restless living", the LFMC was implemented in 2012 based on Article 16 of the National Leisure Revitalization Basic Law, and as of 2019, a total of 154 companies have been certified by 57 large enterprises, 66 small and medium-sized enterprises, and 31 public institutions. LFMC is a situation that has not spread than the family-friendly certification system based on the number of certified companies.

\section{Concepts and Status of Work Innovation Incentive Certification (WIIC)}

The Work Innovation Incentive Certification(Hereafter referred to as WIIC) is a system in which small and medium-sized enterprises voluntarily develop and implement work innovation plans, such as shorter working hours, and benefit from being selected as an excellent company [15]. The aim is to improve longterm work and rigid working practices that are difficult to change through simple consulting and supervisory regulations through voluntary efforts by companies. It was also introduced to create an employment environment for innovation, job creation, and work-life balance in a way that conforms to the Fourth Industrial Revolution and the digital economy. In particular, in 2020, the company intends to establish a permanent working system for "telecommuting", which has spread to COVID-19 pandemics, and to support the spread [16]. The basic legal basis is the Labor Standards Act and the Act on Gender Equality and Support for Work and Family Compatibility, and last year 122 companies applied for participation, 77 companies participated in work innovation, and finally 45 were selected as excellent for workplace innovation. The best company type is $11 \mathrm{SS}$ grades, $17 \mathrm{~S}$ grades, and $17 \mathrm{~A}$-grades. The WIIC was introduced in 2019, and 91 companies will be selected for the first time in 2020, and three months from May 2020, the implementation of the work innovation plan and on-site support consulting are underway. Since then, the second round of corporate recruitment has focused on implementing 'telecommuting. The WIIC is aimed only at small and medium-sized enterprises, as opposed to the FFC and LFMC certifications reviewed earlier. Therefore, large corporations and public institutions cannot be supported by certification and consulting.

\section{Experimental setup}


The researchers used abbreviations to ensure readability and clarify the subject of the repetition of similar words. Just as work-life balance is commonly used as WLB, work-life balance certification will be defined as WLBC, family-friendly certification FFC, leisure-friendly management certification LFMC, and work innovation incentive certification will be defined as WIIC and abbreviated. This was defined by researcher who have been consulting in the field for a long time and is not the official abbreviation of the Korean government

\section{Result discussions}

\section{Empirical analysis results}

General status of WLBC system

Looking at the general status of the work-life balance certification (WLBC) system in [Table 1], the family-friendly certification(FFC) of Ministry of Gender Equality and Family was implem ented in 2008 based on Article 15 of the 'Act on the Promotion of Family-Friendly Social En vironment'. As of 2019, 3,833 companies and public institutions have been certified. In 2012, the Ministry of Culture, Sports and Tourism's Leisure Friendly Management Certification (LFMC) was implemented in 2012 based on Article 16 of the Basic Law on The Activation of National Leisure, and a total of 154 companies were certified in 2019. LFMC separates small and medium-sized enterprises (companies that are outside the scope of small and medium-sized enterprises under the Small Business Act and are not part of a limited group of entrepreneurs) and are certified separately. In addition, the Ministry of Employment and Labor's Work Innovation Incentive Certification (WIIC) was established in 2019 and was selected as one of 45 companies. Features were selected by separating the SS, S, A grades of the excellent companies.

Table 1: General Information of WLBC

\begin{tabular}{|c|c|c|c|}
\hline Classification & FFC & LFMC & WIIC \\
\hline government branch & $\begin{array}{l}\text { Ministry of Gender } \\
\text { Equality and Family }\end{array}$ & $\begin{array}{l}\text { Ministry of Culture, Sports } \\
\text { and Tourism }\end{array}$ & $\begin{array}{l}\text { Ministry of Employment } \\
\text { and Labor }\end{array}$ \\
\hline Grounds law & $\begin{array}{l}\text { Article } 15 \text { of the Act on } \\
\text { the Promotion of Family- } \\
\text { Friendly } \\
\text { Environment }\end{array}$ & $\begin{array}{l}\text { Article } 16 \text { of the Basic Law } \\
\text { on The Activation of } \\
\text { National Leisure }\end{array}$ & $\begin{array}{l}\ulcorner\text { Work Standards Act }\lrcorner \\
\text { and }\ulcorner\text { Act on Equal } \\
\text { Employment for Men and } \\
\text { Women and Support for } \\
\text { Work-Family } \\
\text { Compatibility }\lrcorner \text {, etc. }\end{array}$ \\
\hline $\begin{array}{l}\text { Implementation } \\
\text { year }\end{array}$ & 2008 & 2012 & 2019 \\
\hline $\begin{array}{l}\text { Number } \\
\text { certifications }\end{array}$ & $\begin{array}{l}\quad \text { Total of } 3,833 \\
\text { companies } \\
\text { - large companies: } 408 \\
\text { - SME's: } 2445 \\
\text { - Public institutions: } 980\end{array}$ & $\begin{array}{l}\quad \text { Total of } 154 \\
\text { companies } \\
\text { - large companies: } 29 \\
\text { - midsize company: } 28 \\
\text { - SME's: } 66 \\
\text { - Public institutions: } 31\end{array}$ & $\begin{array}{l}\text { Total of } 45 \\
\text { companies } \\
\text { Ranking Classification } \\
\text { - Class SS: } 11 \\
\text { - Class S: } 17 \\
\text { - Class A: } 17\end{array}$ \\
\hline
\end{tabular}

\section{Incentive and evaluation system of WLBC}

The results of comparative analysis of the review items, score criteria and main incentives for certification policies for this study were summarized as shown in Table 2. In particular, the WLBC incentive comparison results are summarized as follows. Family-Friendly Certification (FFC) provides favorable incentives for companies conducting public procurement bid points, airport fast track cards, and national R\&D projects, etc. The work innovation incentive certification (WIIC) has the advantage of a three-year exemption from regular-time oversight and special military service preferential treatment, so it is recommended that companies that take this seriously be certified. leisure-friendly management certification (LFMC) is found to be good for companies that need to provide leisure programs for their employees.

Table 2: General Characteristic Analysis of Samples

\begin{tabular}{l|l|l|l|ll}
\hline Classification & FFC & LFMC & WIIC \\
\hline $\begin{array}{l}\text { Main Assessment } \\
\text { item }\end{array}$ & $\cdot \begin{array}{l}\text { Restriction } \\
\text { and will }\end{array}$ & & on & $\cdot$ & $\begin{array}{l}\text { Restriction } \\
\text { Overtime work }\end{array}$ \\
\hline
\end{tabular}




\begin{tabular}{|c|c|c|c|}
\hline & 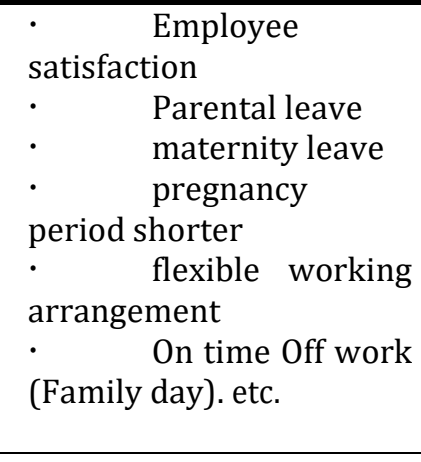 & $\begin{array}{l}\cdot \text { annual leave } \\
\text { utilization } \\
\cdot \quad \text { alternative } \\
\text { holiday system } \\
\cdot \quad \quad \text { compensation } \\
\text { leave system } \\
\cdot \quad \text { Resting place } \\
\cdot \quad \text { Culture and Arts } \\
\text { Program } \\
\cdot \quad \text { Employee } \\
\text { satisfaction, etc. } \\
\end{array}$ & $\begin{array}{l}\cdot \text { On time } \text { Off work } \\
\text { (Family day) } \\
\cdot \quad \text { flexible working } \\
\text { arrangement } \\
\cdot \quad \text { annual leave } \\
\text { utilization } \\
\cdot \quad \text { Employee } \\
\text { satisfaction } \\
\cdot \quad \text { Way of working } \\
\cdot \quad \text { Working culture, } \\
\text { etc. }\end{array}$ \\
\hline Asse & 1 year & 1 year & 1 year \\
\hline Expi & $\begin{array}{lll}\cdot & \text { New 3 years } & \\
\cdot & \text { Extension } & 2 \\
\text { years } & & \\
\cdot & \text { Recertification } & 3 \\
\text { years } & & \\
\end{array}$ & $\begin{array}{lll}\cdot \cdot & \text { New 3 years } & \\
\cdot & \text { Extension } & 2 \\
\text { years } & & \\
\cdot & \text { Recertification } & 3 \\
\text { years } & & \\
\end{array}$ & 3 years \\
\hline Score criteria & $\begin{array}{l}\text { Main 100point, } \\
\text { Additional 15point } \\
\text { large company } \\
\text { Public institutions: } \\
\text { 70points or more } \\
\text { SMEs: 60point or more }\end{array}$ & $\begin{array}{l}\text { Main 100point, } \\
\text { Additional 10point } \\
\text { large company } \\
\text { Public institutions: } \\
\text { 70points or more } \\
\text { medium sized company: } \\
65 \text { point or more } \\
\text { SMEs: 60point or more }\end{array}$ & $\begin{array}{l}\text { Main 1000point, } \\
\text { Additional 80point } \\
\text { SS: } 700 \text { points or more } \\
\text { S: } 600 \mathrm{p} \sim 700 \text { point Less } \\
\text { than } \\
\text { A: } 500 \mathrm{p} \sim 600 \text { point Less } \\
\text { than }\end{array}$ \\
\hline Main Incentive & $\begin{array}{l}\text { airport fast track card, } \\
\text { extra points in public } \\
\text { procurement bids, Bank } \\
\text { interest rate preferential } \\
\text { treatment, } \\
\begin{array}{l}\text { Various by } \\
\text { government, etc. }\end{array}\end{array}$ & $\begin{array}{l}\text { provide leisure programs, } \\
\text { a lecture on humanities, } \\
\text { etc. }\end{array}$ & $\begin{array}{l}\text { exempting regular work } \\
\text { supervision for three } \\
\text { years, Construction cost } \\
\text { of work innovation } \\
\text { infrastructure, } \\
\text { On-site support group } \\
\text { consultation, etc. }\end{array}$ \\
\hline
\end{tabular}

\section{Evaluation index comparison analysis result}

The evaluation index analysis of the certification to the research target was divided into five categories: "Work", "Family", "Leave", "Corporate Culture", and "Interview"). This is summarized in Table 3. Meanwhile, the comparison results between certification systems are as follows. The results of the evaluation index analysis are summarized as shown in Table 3. The results of the comparison of the itemspecific certification system are as follows: First of all, family-friendly certification (FFC) was used as a major indicator of work-related indicators such as family care leave, worker leave, corporate culture creation, and interviews with CEOs, managers and employees. Second, the certification of leisure-friendly management certification (LFMC) focuses on workers' leisure index and is relatively be small in assessment item. Third, the work innovation incentive certification (WIIC) is characterized by the fact that the evaluation index items are evenly distributed, but the family-related items are not major evaluation indicators, but rather additional points. This certification is considered to be somewhat difficult for the certification agency's criteria for 'Selected an excellent company' because it is not easy for SME's managers to prepare an implementation plan for qualitative and quantitative indicators of work innovation.

Table 3: Comparative Analysis Results

\begin{tabular}{|c|c|c|c|c|c|}
\hline category & Evaluation item & FFC & LFMC & WIIC & Remarks \\
\hline \multirow{4}{*}{$\begin{array}{l}\text { (Job) } \\
\text { working hours }\end{array}$} & Restriction on Overtime work & a & 0 & P & Common \\
\hline & On time Off work (Family-day) & 0 & - & P & \\
\hline & early off work & a & - & 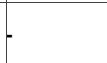 & \\
\hline & flexible working arrangement & ○ & - & P & \\
\hline
\end{tabular}




\begin{tabular}{|c|c|c|c|c|c|}
\hline \multirow{5}{*}{ (Family) } & Parental leave & $\bullet$ & - & a & \\
\hline & $\begin{array}{l}\text { maternity leave } \quad \text { (Spouse } \\
\text { Included) }\end{array}$ & ○ & - & Pa & \\
\hline & $\begin{array}{l}\text { pregnancy period shorter } \\
\text { working hours }\end{array}$ & 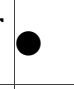 & - & oa & \\
\hline & Workplace Day-care center & a & - & oa & \\
\hline & Family Care leave & a & - & a & \\
\hline \multirow{3}{*}{$\begin{array}{l}\text { leave work } \\
\text { system }\end{array}$} & annual leave utilization & a & $\bullet$ & $\bullet$ & Common \\
\hline & alternative holiday system & - & $\bullet$ & 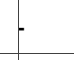 & \\
\hline & compensation leave system & - & $\bullet$ & 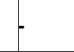 & \\
\hline \multirow{5}{*}{$\begin{array}{l}\text { (Enterprise) } \\
\text { Make up } \\
\text { culture }\end{array}$} & workplace education & a & - & - & \\
\hline & Resting place & - & $\bullet$ & 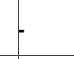 & \\
\hline & Culture and Arts Program & - & $\bullet$ & 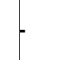 & \\
\hline & $\begin{array}{l}\text { family-friendly program } \\
\text { Way of working (meeting, Task } \\
\text { Concentration, etc.) }\end{array}$ & a & - & b & \\
\hline & $\begin{array}{l}\text { Working culture (Dining } \\
\text { together etc.) }\end{array}$ & & - & $\boldsymbol{\bullet}$ & \\
\hline \multirow{2}{*}{$\begin{array}{l}\text { Interviews } \\
\text { and surveys }\end{array}$} & CEO's interest and will & - & - & - & \\
\hline & Employee satisfaction & ○ & 0 & b & Common \\
\hline
\end{tabular}

[Note: @: Main point, @a: Additional point]

\section{Common and Differences in WLBC}

\section{common ground}

The common elements of the study work-life balance (WLB) three certifications (WLBC) were found to be overtime restrictions, annual use, and employee satisfaction surveys. This is a policy that limits the long hours of current workers, improves employee satisfaction, and reduces work-family conflicts to improve corporate productivity. The key common points are to help resolve conflicts in work-family life through flexible working forms and family cultures in the workplace, solving social problems and pursuing policies for the happiness of the people. Figure 1. showed for common and difference items. 


\begin{tabular}{|c|c|c|}
\hline No. of ele. & WLBC-related ele & \\
\hline 3 & $\begin{array}{l}\text { - Restriction on Overtime work } \\
\text { - Annual leave utilization } \\
\text { - Employee satisfaction }\end{array}$ & $\begin{array}{l}\text { First priority } \\
\text { common }\end{array}$ \\
\hline 7 & $\begin{array}{l}\text { - On time off work(Family-day) } \\
\text { - Pregnancy period shorter working hours } \\
\text { - Parental leave } \\
\text { - Maternity leave } \\
\text { - Workplace Day-care center } \\
\text { - Family Care leave } \\
\text { - Flexible working arrangement }\end{array}$ & $\begin{array}{l}\text { Second place } \\
\text { common }\end{array}$ \\
\hline 4 & $\begin{array}{l}\text { - CEO's interest and will } \\
\text { - Workplace education } \\
\text { - Early off work } \\
\text { - Family-friendly program }\end{array}$ & $\begin{array}{l}\text { FFC } \\
\text { Only }\end{array}$ \\
\hline 4 & $\begin{array}{l}\text { - Compensation leave system } \\
\text { - Resting place } \\
\text { - Culture and Arts Program } \\
\text { - Alternative holiday system }\end{array}$ & $\begin{array}{l}\text { LFMC } \\
\text { Only }\end{array}$ \\
\hline 2 & $\begin{array}{l}\text { - Working culture } \\
\text { - Way of working }\end{array}$ & $\begin{array}{l}\text { WIIC } \\
\text { Only }\end{array}$ \\
\hline
\end{tabular}

Figure 1. Common and Differences in WLBC

\section{Difference}

According to an in-depth analysis of Korea's three major certification systems related to Work and Life Balance (WLB), there is a difference that family-friendly certification(FFC) is divided into family-oriented, leisure-friendly management certification(LFMC) are leisure-oriented, and work innovation incentive certification (WIIC) are corporate and cultural innovation types. Family-friendly certification was used as the main indicators for work-family compatibility, such as childbirth and childcare, On time Off work(family day), and flexible working patterns, and there were high evaluation indexes on the CEO's interest and willingness to practice. It also emphasizes the importance of workplace education to help understand the family-friendly system. The work innovation incentive system focuses on creating jobs and creating an efficient working culture through work-life balance, and evaluates working hours-related and working culture, such as dining and workplace harassment problems, such as meetings, smart factories, and work concentration systems as important indicators. Finally, leisure-friendly entrepreneurship has been shown to use indicators such as culture, art programs, rest, rest area, alternative holidays, and compensation vacation system to improve the quality of life.

\section{Conclusions}

The purpose of this study is to explore implications by comparing and analyzing the relevant contents of the three certification systems implemented by Korean government's 'Work-Life Balance (WLB)' related policies. We analyzed the similarities and differences of those three popular systems. The results of this study are summarized as follows. First, the review edits to the work-life balance certification (WLBC) was implemented an independent certification system (WLBC) to lead the voluntary work-life balance (WLB) of the company in the scope of the agency's jurisdiction. Nevertheless, working hours, annual leave, and employee satisfaction were common indicators. If the Government of the Republic of Korea is preparing for the work-life balance certification, it is desirable to prepare the above three indicators first. On the other hand, it can be perceived that the government's perception of the key indicators for working-life balance (WLB) is centered on "people," or workers. Second, it was confirmed that flexible working, childbirth, and family care indicators are important indicators of certification (WLBC). This indicator is interpreted as an indicator that requires companies to participate because it is important for companies to participate in the prevention of work-family conflicts by forming a family-friendly culture of the company. Third, the difference between the certification (WLBC) is divided into a family-oriented, leisureoriented, corporate culture-oriented. This is in line with the focus policies of the Ministry of Gender Equality and Family, the Ministry of Culture, Sports and Tourism, and the Ministry of Employment and 
Labor. Therefore, it is necessary to select certification that is appropriate for each corporate culture first, and it is necessary to obtain certification step by step through the introduction of additional plans because there are many items with similar screening indicators. On the other hand, the target is the subject has sufficient similarity, but there is an inconvenience in the preparation and examination correspondence from the corporate perspective as it operates independently. The government needs to establish a work-life balance integrated website for applicants to support administrative tasks such as application and issuance, and to monitor and disclose whether certified companies are continuously operating by means of entering data or dispatching consultants, and disclosing them to job seekers. There is a limitation that this study only did literature research and government empirical data analysis. We hope that a family-friendly management culture will be created by further studying the improvement and supplementation of the certification system through surveys and interviews of small and medium-sized enterprises in the future. Nevertheless, SMEs can acquire more information on decision-making on whether they introduce the system or not. It is also meaningful that it attempted for the first time an indepth comparative analysis of the certification system (WLBC) related to work-life balance (WLB).

\section{Acknowledgements}

This research was financially supported by Hansung University.

\section{References}

[1] Information on https://data.oecd.org/emp/hours-worked.htm

[2] Information on https://data.oecd.org/healthstat/suicide-rates.htm

[3] Information http://weekly.khan.co.kr/khnm.html?mode=view\&artid=202003201530501\&code=115/

[4] Hwang K. S. (2019) Phenomenological Analysis for the Employment Policy and Creating Jobs: Understanding Small and Medium-sized Enterprises' Labors and Technology, Journal of Digital Convergence 17:4, 29-39.

[5] Jang H. (2017) A Research on Improving Leisure Friendly Management Certification. Korea Culture \& Tourism Institute, Republic of Korea

[6] Rhee S. U., Hyun E. J. (2018) Local Change Agent for 'Work-Life Balance': Performance Evaluation and Suggestions for Future Directions. Ministry of Employment and Labor, Republic of Korea

[7] Information on https://www.etoday.co.kr/news/view/1881792

[8] Information on https://ec.europa.eu/social/main.jsp?catId=1311\&langId=en

[9] Kwon S. Y. (2019) Dual-Earner Couples' Work Arrangements and Work-Life Balance in Korea: A Person-Centered Approach. Journal of Korean Home Management Association 37(4) Serial No.156, $1 \sim 25$.

[10] Kim D. S., Cho S. T and Sim S. H. (2020) The Effect of Family-Friendly Certification System on Firms' Productivity. Korean Studies Information Service System 25(1), 35-54.

[11] Chung G. W., Hong S. A., Kim N. J., Kim S. J and Sung J. H. (2019) Executive Summary: A Study on the policy for family-friendly social environment formation. Korean Women's Development Institute.

[12] Information on http://www.ffsb.kr/ffm/ffmCertSummary.do

[13] Kang M. J., Moon J. S. \& Lim H. J. (2018) A study on the performance analysis and improvement suggestions of Family-Friendly Certification System. Korean Women's Development Institute.

[14] Information on http://www.rcda.or.kr/business/business9_new.asp

[15] Information on https://www.nosa.or.kr/portal/nosa/majorBiz/mGWrc/WrkinIncnt

[16] Information on http://www.moel.go.kr 